ppi $201502 Z U 4645$

Esta publicación científica en formato digital es continuidad de la revista impresa ISSN-Versión Impresa 0798-1406 / ISSN-Versión on line 2542-3185Depósito legal pp $197402 Z$ U34

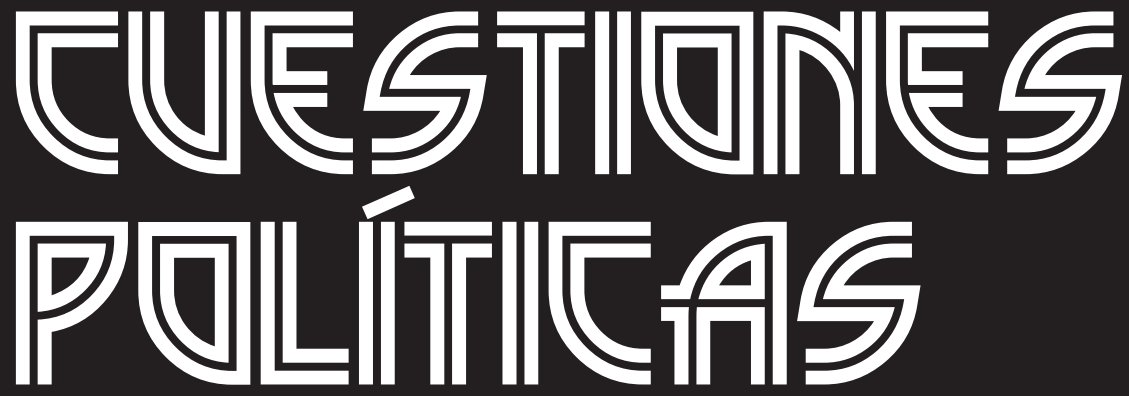

Instituto de Estudios Políticos y Derecho Público "Dr. Humberto J. La Roche" de la Facultad de Ciencias Jurídicas y Políticas de la Universidad del Zulia Maracaibo, Venezuela
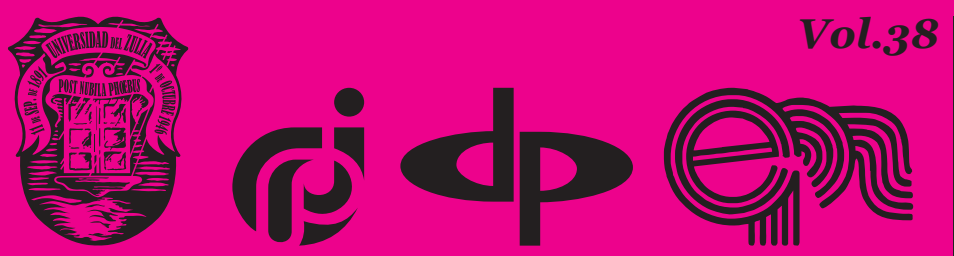

$N^{\circ}$ Especial 1era Parte 2020 


\title{
Victimology: prevention of crimes against the life and health of a child
}

\author{
DOI: https://doi.org/10.46398/cuestpol.38e.23
}

\author{
Zeleniak Polina * \\ Kulakova Nataly ** \\ Mozol Stanislav *** \\ Dordiai Volodymyr **** \\ Mozol Nataliya
}

\begin{abstract}
The objective of the article is to propose a renewed protection system for children in the prevention of crimes against life and health. The research methodology is based on the combination of dialectical, formal, dogmatic, sociological, comparative law and documentary methods. The results of the study contributed to the development of measures to guarantee the safety of the child, which means a set of legal, economic, organizational measures, which are carried out by the public powers and the administration, with the aim of neutralizing and preventing usurpation of the life and health of children in Ukraine. Organizational and legal measures have been implemented to improve the interaction of the National Police with the services of children and special institutions for children by carrying out joint activities to prevent and identify possible invasions into the life and health of the child. It is concluded that in order to determine the characteristics of the subject, namely, crimes against the life and health of the child, it is necessary to improve the legislation in the interaction of the actors to
\end{abstract} prevent this type of crime.

PhD (Law), Lecturer of the cycle of general and criminal law disciplines of Kyiv Center for Primary Vocational Training of the Police Academy of the Research Institute № 1 of the National Academy of Internal Affairs, Ukraine. ORCID ID: https://orcid.org/oooo-0003-0615-0803. Email: post@naiau. kiev.ua

** PhD in Law, Associate Professor, Professor of the Department of Criminology and Penal Law of the National Academy of Internal Affairs, Ukraine. ORCID ID: https://orcid.org/oooo-0003-4119-1686. Email: post@naiau.kiev.ua

*** Doctor of Law, Senior Researcher, Associate Professor of the Department of Criminology and Penal Law of the National Academy of Internal Affairs, Ukraine. ORCID ID: https://orcid.org/oooo-00o22226-7908. Email: post@naiau.kiev.ua

*** PhD in Law, Lecturer of the Department of Administrative, Financial and Information Law of State Higher Educational Institution "Uzhhorod National University", Ukraine. ORCID ID: https://orcid. org/oooo-ooo1-5419-3993. Email: official@uzhnu.edu.ua.

*****PhD in Law, Associate Professor, Associate Professor of the Department of State and Law of the National Academy of Internal Affairs, Ukraine. ORCID ID: https://orcid.org/oooo-0003-4296-3932. E-mail: post@naiau.kiev.ua 
Keywords: crimes against the life and health of the child; victimological prevention measures; victimological safety; measures to ensure the safety of the child; Ukraine.

\section{Victimología: prevención de delitos contra la vida y la salud de un niño}

\section{Resumen}

El objetivo del artículo es proponer un renovado sistema de protección para los niños de prevención de delitos contra la vida y la salud. La metodología de investigación se basa en la combinación de los métodos dialéctico, formal, dogmático, sociológico, de derecho comparado y documental. Los resultados del estudio contribuyeron al desarrollo de medidas para garantizar la seguridad del niño, lo que significa un conjunto de medidas legales, económicas, organizativas, que son llevadas a cabo por los poderes públicos y la administración, con el objetivo neutralizar y prevenir la usurpación de la vida y la salud de los niños en Ucrania. Se han implementado medidas organizativas y legales para mejorar la interacción de la Policía Nacional con los servicios de la niñez y las instituciones especiales para la niñez mediante la realización de actividades conjuntas para prevenir e identificar posibles invasiones a la vida y la salud del niño. Se concluye que para determinar las características del tema, a saber, los delitos contra la vida y la salud del niño, es necesario mejorar la legislación en la interacción de los actores para prevenir este tipo de delitos.

Palabras clave: delitos contra la vida y la salud del niño; medidas de prevención victimológica; seguridad victimológica; medidas para garantizar la seguridad del niño; Ucrania.

\section{Introduction}

The Constitution of Ukraine places the highest value on a person, his (her) life and health, honor and dignity, inviolability, and security as the highest social value (Article 3). The State guarantees the protection of the family, childhood, motherhood and fatherhood (Article 51), as well as the protection of children from violence (Article 52). However, despite State guarantees, the problem of domestic violence against children in Ukraine is acutely social and requires adequate measures to respond to it at various levels. The problem of domestic violence against children has not been discussed outside the family for a long time, due to the isolation of family relations from society and the belief that the choice of methods 
of upbringing a child is a personal matter for each family. However, at the present stage, the international community has recognized such violence as one of the most common forms of violation of the natural rights of the child. Childhood is one of the most important stages of human development, when the fundamental moral qualities, the foundations of the interaction of an individual with the society (in the family, in educational institutions, and in the future - with the colleges, etc.) are laid. Therefore, violence against children poses a great threat not only to their physical and mental health, but also to their further normal socialization in general. The importance of protecting the child's right to life and health led to the choice of the topic of the scientific article and facilitated consideration of this issue from the standpoint of criminology and victimology in order to develop specific proposals and practical recommendations for identifying signs of crimes, identifying their determinants and developing ways of prevention.

A significant number of scientific findings indicate that the problem of the effectiveness of preventive measures in this area remains relevant. Unfortunately, today there is no research in the field of victim prevention of crimes that encroach on the life and health of the child, in conditions of deteriorating crime. The current situation is due to the shortcomings of preventive activities not only of police units, but also of services for children, families and youth. All this determines the relevance and timeliness of the definition of measures to ensure the safety of life and health of the child as a special object that needs immediate improvement.

The aim of the article is to develop measures for the victimological safety of the child, namely to prevent crimes against the life and health of the child, which should be reflected in law and practice. Also with the aim of clarifying the nature of child victimization, the factors that contribute to this, as well as the development on this basis of scientifically sound recommendations aimed at preventing and stopping crimes against life and health of children, improving the effectiveness of existing forms and methods of preventing crimes.

\section{Literature Review}

The issue of protection of life and health of a person in general and a child in particular has been repeatedly addressed in legal science, and various aspects of this legal institution have been studied depending on the area of law. For example, Mussayev (2018) focuses on the peculiarities of victimological prevention of criminal offense against human life and health. He investigated different methods to improve the preventive measures system for crime against life and health by studing the experience of some foreign countries on this issue and allocating the main trends in 
protecting crime victims used in these States. The Author also presented his own system of measures aimed at preventing crimes against life and health based on the comprehensive study of international experience.

Resented comprehensive analyses of such institutions of law as victimology and crime prevention. The Authors believe that victimology and crime prevention have developed in parallel and insist on autonomous nature of these institutions, which, however, are closely connected with such disciplines as sociology, law, criminology, medicine, economics, psychology, etc. They examined a lot of issues within the research, among which are: crime prevention, personal offenses, school offenses, schoolbased crime prevention, victimology and so on.

Frieze, et al (1987) focused their attention on the physiological response of victims to the crime committed against them. The authors believe that the consequences of such a reaction could be much more severe than physical injury or material damage caused (for example, loss of a sense of self, a loss of safety or invulnerability, and feelings of inequity or injustice). Special attention is paid to the issue of children who are victimized.

Besides, the study used the results of scientific researches of such scholars as T. Wind, and Silvern (1992), who considered the issue of type and extent of child abuse; Giarbarlo (1995), who proposed some of the therapeutic methods of exit counseling; Baron and Richardson (1994), who investigated the development of aggression, biological bases of aggressive behavior, and aggression in natural settings and Abdulgaziev et al (2018), who examined the interconnection between family welfare and the crime rate among children.

Among Ukrainian scientists these problems was studied by Dzhuzha (1998), Tuliakov (2000), Zelenyak (2018) and some others.

\section{Materials and methods}

The methodological basis of the article is the dialectical-materialist method of cognition of reality. The study used a dialectical method of cognition of reality, as well as special theoretical and sociological methods, in particular: comparative law - in determining the legal responsibility for encroaching on the life and health of the child, which allowed to study the legislative experience of foreign countries, statistical - when studying data on the state, trends of investigated crimes and characteristics of persons committing crimes against the life and health of children, sociological in the process of studying the opinions of practitioners of Ukraine on the factors that determine the commission of investigated crimes and study the materials of criminal proceedings. violated for crimes against the life and 
health of the child, logical and normative - when formulating proposals for amendments to current legislation in order to prevent crimes against the life and health of the child.

The research is also based on the documentary method for collection sociological information, with was used in the course of the study of official statistics of the National Police of Ukraine during 2013 - 2019, the results of opinion polls of 309 investigative territorial units of the National Police and materials of 284 criminal cases and criminal proceedings for 2009 2019.

\section{Results and Discussion}

Currently, Ukraine has an extensive system of regulations that directly enshrine the legal mechanism for ensuring, protecting and defending the rights of the child. It should be noted that this mechanism generally complies with international standards in the field of children's rights, which are enshrined in the relevant regulations. Art. 6 of the Family Code of Ukraine (Law of Ukraine, 2002) defines "the legal status of the child as a person before reaching adulthood. A child is considered a minor until he or she reaches the age of fourteen. A child between the ages of fourteen and eighteen is considered a minor".

Despite the large number of scientific studies that have formulated the fundamentals of criminological victimology and the system of victimology prevention, further research today requires the protection of children from crimes against life and health, as well as the development of victimology safety for children.

The importance of protecting the life and health of a child is unquestionable, as provided by domestic law - the features of criminal liability for encroachment on the life and health of the child. The specificity of the child as a victim is due to age, level of knowledge, limited life experience, conformal qualities, etc. This contributed not only to the selection of aggravating features in criminal law (Law of Ukraine, 2001), but also to the development of a system of protection for this category of the population.

But despite the current system of measures, crimes against the life and health of children account for up to $7 \%$ of the total crime (Prosecutor's General Office of Ukraine, 2020). Therefore, there is an urgent need to develop a system to ensure the safety of the child from crimes against life and health, namely in the form of victim prevention measures. It is important to understand the potential victimhood of the child is to determine the environment in which the child is, the process of its formation, victimogenic 
factors and conditions. As the process of victimization is dynamic, due to the interaction of various components - a set of circumstances in the life of the child and society, which determine the process of transforming the individual into a victim of crime, they in one way or another contribute to its implementation. The conditions of victimization are various phenomena of objective and subjective nature, which increase the child's ability to become a victim of crime, as certain properties of the child determine the degree of its vulnerability to crime.

According to the research, the potential nature of the child's victimhood is enhanced when the study is from a single fact, from the level of personality to the level of social group. The content of the child's victimhood is a personal and situational components. The personal component of a child's victimhood contains qualities of a subjective nature, which contributes to increased vulnerability to encroachments on life and health. The situational component of victimhood contains a set of objective circumstances that form personal components, or increase their role and importance in the process of victimization of the child (Malkina-Pykh, 2010).

One cannot but agree that the main factors of victims' victimhood are their age, which results in incomplete formation of a person in biological terms, and given this - the inability to resist criminal encroachment and socially, the inability to adequately assess the situation, which leads to greater likelihood to a criminogenic situation as a victim of a crime.

The scientists divide the victims' traits that are inherent in children into two groups - general and individual ones (Dzhuzha, 2015; 2017; Moiseiev, 1998; Tuliakov, 2000). Gereral traits are: gullibility, naivety, curiosity, inability to adequately respond to the situation, mental retardation from physical, the predominance in mental activity of the processes of excitation from inhibition, physical weakness.

Individual mental properties are divided into biopsychological, psychological and socio-psychological. The actual psychological traits are: aggression, anxiety, cruelty, riskiness, emotional imbalance. Sociopsychological traits are: the need for communication, self-affirmation, ignorance of the main methods of personal security. Psychological factors are: type of temperament, the presence of certain characteristics. Besides, some foreign scientists identify the factors associated with: objectively low socio-economic status of the family (Fattah, 1989), single-parent family (Wind and Silvern, 1992), the norms and style of communication and upbringing of a child (Giarbarlo, 1995; Frieze et al, 1989).

The interaction of subjective and objective factors not only leads to the victimization of the child, but also contributes to the process of turning the child into a potential victim. Therefore, during the research the determinants of victimization it is necessary to determine the mechanism, 
which is a system of elements and stages of change in the victimhood of the child due to the interaction of external and internal factors. In this case, the objective (external) component is a set of conditions that exist in society and which are characterized by victimogenic potential, and subjective (internal) factors constitute a system of mental processes that form the victim motivation of behavior. Victim prevention should help not only to identify specific life circumstances of the potential victim, but also to model the victim situation, taking into consideration social mechanism of victimization. Increased victimization of children is determined not only by their psychophysiological qualities, but also by their social roles, the place in the system of social relations, the position they occupy in the family.

Today, a model that explains the mechanism of child victimization has been developed. Examining the cycle of development of aggressive tendencies in a child, it has been found that children who have been abused are more aggressive towards other children - the "index of aggression" for the offended child was 93\% higher than for other children. This is especially true for children who have been subjected to domestic violence. Such a child is less able to process information and solve problems of interpersonal communication in a tolerant form. The pattern of aggressive behavior reproduced in early childhood can extrapolate to future actions (Baron and Richardson, 1994). Victimization of a child thus determines the criminalization of an adult. Accordingly, the task of victimological prevention is to prevent this.

Of particular concern is the increase in the number of crimes under investigation against minors. And it is crimes committed by parents and relatives. Such crimes have a high level of latency, which is facilitated by fear of adults and the belief that no one will be able to help a child. Sometimes it is impossible to distinguish between child abuse and criminal neglect of the child. The feelings of fear or shame in front of friends and acquaintances, fear of condemnation or ridicule, which is characteristic of the child's environment, the child's desire not to talk about what is happening. Internal experiences negatively affect on the child's development (Zelenyak, 2019). In our opinion, crimes against the life and health of a child should be investigated not only as a criminal law problem, but also, first of all, as a social one.

As a result of studying the materials of criminal cases and criminal proceedings, the so-called "secondary" victimization was established, which appears during the reproduction of the circumstances of the crime. Particular attention in the interview with the child should be paid to the crime committed. In this case, tactless, rude behavior or contempt for the child, its condemnation are unacceptable. The victim's rejection by her immediate environment, misunderstanding and condemnation will contribute to desocialization - escape from home, family, alcohol, drugs, 
exposure to a deviant environment and, as a consequence, secondary victimization.

The identification of all social phenomena and processes in the relationship is of great importance for the development of victimological security measures that will help minimize (neutralize) the phenomena and processes that give rise to crime. Victimological security is understood as a set of measures carried out by state bodies, public organizations, individuals, aimed at a potential victim (child), the application of which reduces the possibility of becoming a victim of crimes against life and health (Zelenyak, 2018,).

The development of victim safety measures should be based on: a set of knowledge about the victim, the peculiarities of his (her) behavior before, during and after the crime, the specifics of the relationship "criminal victim", specific life circumstances that led to the transformation of a person into a victim. The task of such activities at the present stage is scientific explanation and forecasting of victimological processes in order to intensify the preventive impact on crime based on non-traditional approaches, which will focus on the person (child) who in certain circumstances may become a victim of criminal encroachment.

Today the legal basis for preventive activities is: the UN Declaration of Basic Principles of Justice for Victims of Crime and Abuse of Power, criminal procedural and criminal legislation of Ukraine, which reflects and partially solves some of the general issues of victimological crime prevention, Laws of Ukraine "On the National Police", "On Prevention and Counteraction to Domestic Violence", "On Social Services", "On Agencies and Services for Children and Special Institutions for Children", Decree of the President of Ukraine "On the Concept of Protecting the Legal Rights and Interests of Victims of Crime", etc.

A complex multi-subject system of neutralization of victimization of both the population as a whole and individual social groups has also been formed. This system is a set of practical measures to transform social relations in accordance with the goal of devictimization of the individual, reducing the negative consequences for society of criminal excesses, the reproduction of the rule of law and the principle of justice.

According to the results of the study, it should be noted that the identification of potential victims should be built in three directions: 1 ) on the part of the situation when, identifying and analyzing the situation, one comes to potentially affected in this situation; 2) on the part of the offender, when by studying his (her) connections or typical behavior, the range of possible potential victims of his (her) actions is determined; 3 ) on the part of the victim, when the determination of a particular person reveals his (her) inherent victim qualities (Zelenyak, 2018). Such activities are entrusted to State agencies, public organizations, officials, citizens. 


\section{6}

Zeleniak Polina, Kulakova Nataly, Mozol Stanislav, Dordiai Volodymyr y Mozol Nataliya Victimology prevention of crimes against the life and health of a child

It should be noted that crimes against the life and health of children are the result of conflict situations that are periodic, long-term in nature with increasing severity, exacerbation. And this is where the special social danger of crimes against children manifests itself, which requires constant improvement of work to prevent it. Neutralizing conflict situations through the use of influence on the parties to the conflict is an effective way to prevent crimes against the lives and health of children. It is through the use of early prevention measures, which includes preventive measures in the application of psychological and pedagogical skills and abilities to prevent the commission of a crime, which aims to restructure the consciousness of the individual who may commit a crime against the life and health of the child. The method of early prevention includes the implementation of a wide range of educational measures.

Among the measures aimed at preventing the commission of crimes against the life and health of a child are the measures aimed at identifying persons suffering from various diseases, primarily mentally ill persons who show various forms of aggression. The main burden of identifying these individuals should be on psychologists and psychiatrists. Today, in the context of health care reform, citizens are afraid to turn to psychologists and psychiatrists because of the fear of disclosure. As a result, these diseases only complicate, which makes such persons to commit the crimes under investigation. Excessive administration will contribute to the separation of such people from the professional help of doctors, and thanks to anonymous measures to provide psychological and psychiatric care, people can turn to help. The police should be informed only in cases where persons are, in the opinion of a doctor, are possible offenders, who can commit crime against life and health, and the behavior of such persons is not amenable to permanent correction. Besides, the identification of such persons, if they have not committed a crime, should not contain any punitive measures; medical measures should be applied only under conditions of strict confidentiality. Such identification of persons is necessary, first of all, in order to carry out individual work with them, to apply measures of individual prevention. The police officers must properly warn these people about the inadmissibility of committing crimes against the life and health of a child.

Particular attention should be paid to identifying persons suffering from aggression among the employees of educational institutions. There is an objective need to introduce mandatory testing of all educators involved in the educational process by the experienced psychologists and psychiatrists at the legislative level, regardless of the permanent or temporary nature of such work.

In connection with the above, it is quite important to supplement the Labor Code of Ukraine with the provisions, which would enshrine the restrictions on employment in education, upbringing, child development, 
recreation and health, medical care, social services, children's sports, culture and art with the participation of children. Sadly, the mechanism for implementing the adopted legislation has not yet been developed. Thus, a person hired must provide the employer with the documents and a certificate of criminal record and facts of criminal prosecution, including terminated, but the form of such a certificate is not approved by the Ministry of Internal Affairs of Ukraine. There are also restrictions on the presence of some diseases, but the Ministry of Health has not approved the list of these deseases.

We consider it possible to divide the measures of individual influence into two types: the measures of persuasion and the measures of help. Persuasion measures are both protective and educational: conversations, explanations on how not to become a victim of crime, how to ensure the preservation of health and property. Alcohol intoxication of the victim is a condition that contributes to the commission of some crimes, so victimological prevention is largely to reduce the level of alcoholism of our citizens. Assistance measures primarily include the organization of special counseling centers, centers for social and psychological protection of citizens from crime, the main task of which is to inform the public about measures to protect against crime. It is necessary to organize group and individual consultations with potential victims of crimes, during which to provide them with social and psychological assistance, predict their individual victim behavior, identify and try to neutralize victimologically significant personality traits and behaviors in the centers of psychological assistance.

Psychoprophylactic work with children on devictimization (an active learning of socially important skills) is of particular importance today. Such activities can be implemented in the form of group exercises (trainings), for example in educational institutions.

Careful analysis of the factors that contributed to the encroachment on the life and health of the child will also contribute to the application of precautionary measures. Information on the areas where these crimes are committed, the intoxication of persons and the lack of understanding of the damage should be documented, investigated and analyzed in order to apply the most effective prevention measures, taking into account the safety of life and health of a child.

Promoting the safety of the child, which should include the dissemination of regulations in the area of ensuring the rights and interests of the child; informing the population about crimes related to the encroachment on the life and health of the child and their consequences; advertising of various organizational events. Activities to promote the safety of life and health of the child are aimed at the legal education of citizens to prevent violations of the rights and interests of the child. 


\section{Conclusion}

According to the results of the study, measures of general social prevention of crimes against the life and health of children in Ukraine have a system of measures to ensure the "safety of the child". The definition of "child safety" refers to the protection of the life and health of a child from real and potential threats, which is a priority of state bodies, local governments, their officials and the public. The measures "ensuring the safety of the child" mean a set of legal, economic, organizational measures carried out by public authorities and administration, which are aimed at ensuring the neutralization and prevention of encroachments on the life and health of the child in Ukraine. These include:

1) legal regulation in the field of ensuring the safety of development and life of the child;

2) identification of threats to the life and health of the child;

3) assessment of the possible needs of a child who found himself in difficult life circumstances;

4) development and implementation of requirements for ensuring the safety of life and health of the child;

5) classification of measures to ensure compliance with the safety of life and health of the child;

6) development and implementation of measures to ensure the safety and health of the child;

7) training of specialists in the field of ensuring the safety of life and health of the child;

8) State control and monitoring of the situation in the field of ensuring the safety of life and health of the child;

9) legal, informational, logistical and scientific and technical support for the safety of life and health of the child.

Unfortunately, today the proposed measures are not able to solve all the problems, but together with traditional prevention measures can significantly increase the level of crime prevention, creating an opportunity for comprehensive measures, increasing its effectiveness, and be logically consistent and complete. However, to ignore the possibilities of victim safety measures, and even more so to ignore them, means to fight crime, namely crimes against the life and health of children, only in part. 


\section{Bibliographic References}

ABDULGAZIEV, Rustam, ZHUKOVA, Tatyana, SUKHORUKOVA, Anastasiya, MAMICHEV, Viktor, ARSHINOV, Albert \& ALSULTANOV, Magomed. 2018. "Family welfare as a basis of fighting crime" In: Amazonia Investiga. Vol. 7, No. 17, pp. 143-149.

BARON, Robert; RICHARDSON, Deborah. 1994. Human Agreesion. Plenum. New York, United States.

DZHUZHA, Oleksandr; MOISEIEV, Yevhen. 1998. Problems of the victim of crime (criminological and psychological aspects): monograph. National Academy of Internal Affairs. Kyiv, Ukraine.

DZHUZHA, Oleksandr. 2015. Crime prevention: criminological and victimological paradigm: monograph. National Academy of Internal Affairs. Kyiv, Ukraine.

DZHUZHA, Oleksandr. 2017. Victimological principles of crime prevention in Ukraine: theory and practice: monograph. National Academy of Internal Affairs. Kyiv, Ukraine.

FATTAH, Ezzat. 1989. "The Child as Victim: Victimological Aspects of Child Abuse". In: Fattah, E.A. (eds). The Plight of Crime Victims in Modern Society. Palgrave Macmillan. London, UK.

FRIEZE, Irene; HYMER, Sharon; GREENBERG, Martin. 1987. "Describing the crime victim: Psychological reactions to victimization" In: Professional Psychology: Research and Practice, No. 18 (4), pp. 299-315.

GIARBARLO, Carol. 1995. Exit counseling: A family interventions. American Family Foundation. Bonita Spring, United States.

LAW OF UKRAINE. 2001. Criminal Code of April 05, 2001 no. 2341-III. Available online. In: http://zakon.rada.gov.ua/laws/show/2341-14. Date of consultation: 27/05/2020.

LAW OF UKRAINE. 2002. Family Code of January 10, 2002 no. 2947-III. Available online. In: https://zakon.rada.gov.ua/laws/show/294714\#Text. Date of consultation: 27/05/2020.

MALKINA-PYKH, Irina. 2010. Victim's psychology. Moskow: Eksmo.

MUSSAYEV, Daniyarbek. 2018. "Victimological Prevention of Crime against Life and Health" In: Journal of Advanced Research in Law and Economics. Vol. 8, No. 5, pp. 1585 - 1591. Available online. In: https://journals. 
Zeleniak Polina, Kulakova Nataly, Mozol Stanislav, Dordiai Volodymyr y Mozol Nataliya

370

Victimology prevention of crimes against the life and health of a child

aserspublishing.eu/jarle/article/view/1718. Date of consultation: 27/05/2020.

PROSECUTOR GENERAL'S OFFICE OF UKRAINE. 2020. Statistical information on the registered criminal offenses and results of their pre-trial investigation. Official web-site of Prosecutor's General Office of Ukraine. Available online. In: https://old.gp.gov.ua/ua/ stst2011.html?dir_id $=114140 \& l i b i d=100820 \& c=$ edit\&_c=fo. Date of consultation: 27/05/2020.

TULIAKOV, Viacheslav. 200o. Victimology: social and criminological problems. Legal Literature. Odesa, Ukraine.

WIND, Tiffany; SILVERN, Louise. 1992. "Type and extent of child abuse as predictors of adult functioning" In: Journal of Family Violence. No. 7, pp. 261-281.

ZELENYAK, Polina. 2018. "Characteristics of Persons Committing Violent Crimes against Children" In: Scientific Bulletin of the National Academy of Internal Affair. Vol. 109 No. 4, pp. 325-335.

ZELENYAK, Polina. 2019. Features of victimization of children from crimes against life and health. Presented at the interuniversity scientific and practical round table. Criminological theory and practice: experience, current problems and the ways to solve them. Kyiv, Ukraine. 


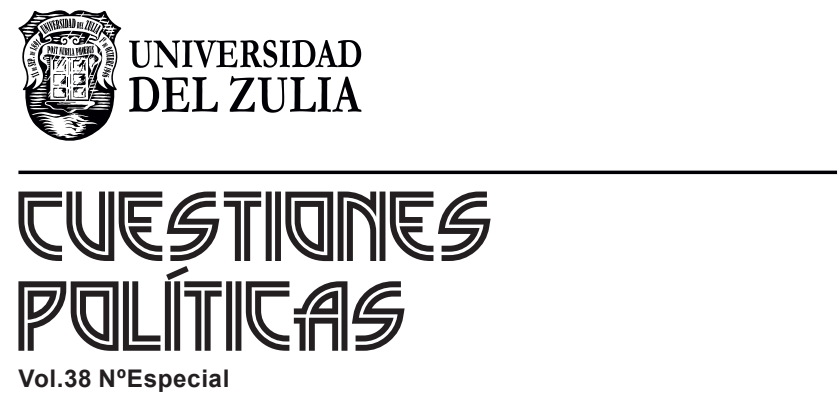

www.luz.edu.ve 